\title{
Effects of Shading in Summer on Yield and Quality of Tomatoes Grown on a Single-truss System
}

\author{
Teruo Wada*, Hideo Ikeda, Kenji Matsushita, Akira Kambara, Hiroaki Hirai and Kazuhiro Abe \\ Graduate School of Agriculture and Biological Science, Osaka Prefecture University, Sakai 599-8531, Japan
}

\begin{abstract}
This study was conducted to examine the yield and quality of tomato fruits grown on a single-truss system shaded during the summer. Tomato seeds were sown on the 10th of every month from February to September and the seedlings were grown in NFT. The plants were covered with cheesecloth at the shading level of 0 (control), 30 (light shading), 55 (medium shading), and 83\% (heavy shading) from 10 days after the first anthesis. The nutrient solution was cooled to $25^{\circ} \mathrm{C}$ from July to September. As the shading level increased, total fruit yield decreased with loss of fruit weight. The total fruit yield of each crop was individually correlated linearly with the mean value of daily integrated solar radiation during fruit development. Regression analysis indicated that the decrease of total fruit yield, corresponding to the loss of $1 \mathrm{MJ} \cdot \mathrm{m}^{-2}$ of the daily integrated solar radiation, would increase from 84 to $100 \mathrm{~g}$ /plant if the average air temperature increased from 19 to $27^{\circ} \mathrm{C}$. Marketable fruit yield in the control plot was highest in the Feb. crop and significantly lower from Apr. crop to Jul. crops, because of the high incidence of cracked fruits. The incidence of cracked fruits was decreased by shading. It was estimated that shading which decreased daily integrated solar radiation to $5-6 \mathrm{MJ} \cdot \mathrm{m}^{-2}$ effectively increased marketable fruit yields when the air temperature exceeded $25^{\circ} \mathrm{C}$. Summer harvested fruits had high titratable acidity. Shading was apt to decrease the brix and increase the titratable acidity of fruits.
\end{abstract}

Key Words: quality, shading, single-truss, tomato, yield.

\section{Introduction}

Predicting harvest date or yield of tomatoes grown on a single-truss production system is easier than that on an ordinary multi-truss system. Therefore single-truss tomato production system has been studied as a scheduled production system (Giniger et al., 1988; Kobayashi et al., 1998; McAvoy et al., 1989). Response of tomato plants, grown on the single-truss system, to some environmental conditions may differ from those grown on the ordinary multi-truss system. Hence we deemed it important to determine the effects of environmental conditions on the yield and quality of tomato fruits grown on a single-truss system. Effects of minimum air temperature in winter (Wada et al., 1998, 2001), shading (Sato et al., 1994; Yanagi et al., 1995), and salinity stress (Sakamoto et al., 1999) on yield and quality of single-truss tomatoes have been reported.

It is known that the range of optimum air temperature is from $13-14$ to $27-28^{\circ} \mathrm{C}$ and upper limit of air temperature is $30^{\circ} \mathrm{C}$ for growing tomato plants (Saito, 2004). However, air temperature in a greenhouse often goes over $30^{\circ} \mathrm{C}$ in summer which can caused leaf scorch, low fruit set, and the incidence of small fruits (Iwahori et al., 1963). High air temperature and strong solar

Received; October 22, 2004. Accepted; June 8, 2005.

* Corresponding author (E-mail: wadoo@bioinfo.osakfu-u.ac.jp). radiation also cause sunscald or uneven ripening in tomato fruits (Lipton, 1970; Mulholland et al., 2003; Slack et al., 1988). To prevent strong solar radiation and excessively high air temperature, cheesecloth is usually used in the greenhouse production during the summer. However, shading reduced the fruit yield of tomatoes (Cockshull et al., 1992; Nasiruddin et al., 1995; Sato et al., 1994). Light condition affected fruit quality of tomatoes (Davis and Hobson, 1981; McCollum, 1946; Yanagi et al., 1995). However, there are a few papers about the effects of solar radiation on the yield and quality of tomato fruits during the summer because of the difficulty of growing tomatoes under high temperature.

In this study we tried to determine the yield and quality of tomato fruits that were shaded during the summer growing season.

\section{Materials and Methods}

'Momotaro' seeds were sown on the 10th of every month from February to August in a seeding tray filled with vermiculite. The tray was kept in the growth chamber at $27^{\circ} \mathrm{C}$. When seeds were sown on February, the crop was called Feb. crop. Other crops were also called Mar. crop, Apr. crop, etc. After germination each tray was transferred to the greenhouse, covered with polycarbonate film $(5.4 \mathrm{~m}$ width, $13 \mathrm{~m}$ length, and $3 \mathrm{~m}$ height). When the second true leaf appeared, the seedlings were transplanted into $5 \times 10 \times 10 \mathrm{~cm}$ 
(height $\times$ length $\times$ width) rockwool cube and grown on NFT bed. Half-strength of Otsuka-A nutrient solution (Otsuka Chemical Co., Ltd., Osaka) was supplied from the front and rear ends of the bed for 15 min every $30 \mathrm{~min}$ during the day and every hour during the night. The composition of the nutrient solution $\left(\mathrm{mg} \cdot \mathrm{L}^{-1}\right)$ was: $\mathrm{NO}_{3}$ $\mathrm{N}, 112 ; \mathrm{NH}_{4}-\mathrm{N}, 9 ; \mathrm{P}, 62 ; \mathrm{K}, 156 ; \mathrm{Ca}, 160 ; \mathrm{Mg}, 48 ; \mathrm{S}$, 64; Fe, 2.85; B, 0.32; Mn, 0.77; Zn, 0.04; Cu, 0.02; Mo, 0.02 . EC and $\mathrm{pH}$ of the solution was $1.4 \mathrm{dS} \cdot \mathrm{m}^{-1}$ and 6.3 , respectively. When the buds of the first inflorescence appeared, seedlings were spaced at intervals of 38 and $26 \mathrm{~cm}$ between and within the rows, respectively.

Shading was started 10 days after the first anthesis in each crop and was carried out by covering plants with cheesecloth (Fig. 1) at the shading levels of $0 \%$ (no cover), 30\% (white), 55\% (black), and 83\% (black). They were called control, light shading, medium shading, and heavy shading, respectively. The front and rear ends of the bed were not covered by cheesecloth to improve the ventilation of the plant canopy. Each treatment had 4 blocks and each block contained five plants. The blocks were calculated as replications of each crop. Plants were pruned, leaving 2 leaves above the first truss and trained to single-truss at the first anthesis in the first truss. Flowers were sprayed with 4-chlorophenoxy acetic acid (4-CPA) to improve fruit set. The greenhouse was ventilated by a fan when the air in the greenhouse reached $27^{\circ} \mathrm{C}$. Both sides of the greenhouse were fully open, and the nutrient solution supplied to the plant roots was cooled to $25^{\circ} \mathrm{C}$ from July to September. The air temperature in greenhouse was maintained at $15^{\circ} \mathrm{C}$ by heating during February to mid-April and the following
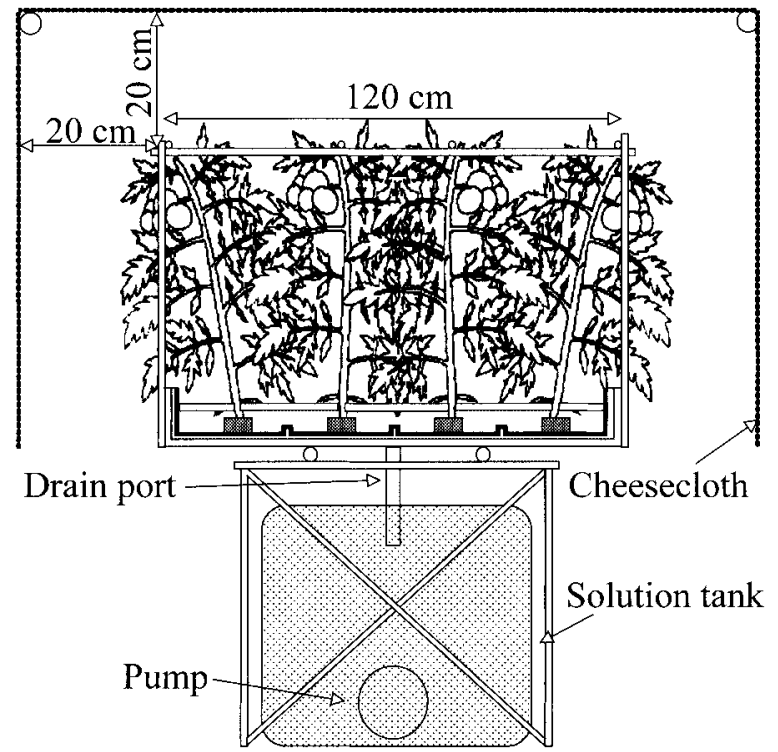

Fig. 1. Schematic figure of single-truss system of tomato used in this study. Nutrient solution was pumped up and supplied to the plant roots by NFT system from both front and rear ends of the bed, and returned to the solution tank from a drain port on the center of the bed.
November.

Air temperatures of each treatment in the greenhouse were measured with thermocouples $(\phi=0.32 \mathrm{~mm})$ at the level of plant canopy under the cheesecloth. Solar radiation was measured with Pyranometer (Li-cor co., ltd., USA) outside of the greenhouse. Solar radiation in the greenhouse was calculated by multiplying light transmittance of the greenhouse to outside solar radiation.

Fruits were harvested 3 times weekly. Cat-faced, irregular, puffy, blossom-end rot, cracked fruits, and fruits which weighted less than $50 \mathrm{~g}$ were classified as unmarketable. After classifying fruits, the fresh weight of each fruit was recorded.

Five mature fruits were collected from each treatment from Apr. crop to Jul. crop to determine their brix and titratable acidity. The fruits were homogenized by a blender and the homogenates filtered through fourlayered cheesecloth. The brix and titratable acidity of the filtrates were recorded. Brix was measured by reflactometer (PR-101, Atago co., ltd., Tokyo). Titratable acidity was determined by titration with $0.1 \mathrm{~N} \mathrm{NaOH}$ to an end point of $\mathrm{pH} 8.0$ with a $\mathrm{pH}$ meter (D-12, Horiba co., ltd., Kyoto).

\section{Results}

Seasonal change of daily air temperature and integrated solar radiation under control in the greenhouse (Fig. 2) shows that the former was more than $25^{\circ} \mathrm{C}$ for most of days from July to September, the maximum and the minimum air temperatures (data not shown) during these days were more than $30^{\circ} \mathrm{C}$ and $20^{\circ} \mathrm{C}$, respectively. The air temperature decreased quickly after the end of September. However, the air temperatures were not affected by any shading (data not shown) because of good ventilation. The daily integrated solar radiation was high from April to August and declined after August. Solar radiation dropped from late May to early June and into September because of seasonal rains. Two big drops of solar radiation in July were caused by a typhoon.

The crop data (Table 1) reveal that the average air temperature in seedling stage exceeded $26^{\circ} \mathrm{C}$ during the Jun., Jul., and Aug. crops, whereas that during fruit development, which extended from the first anthesis to the first fruit harvest, in control was more than $25^{\circ} \mathrm{C}$ in May, Jun., and Jul. crops. The mean daily integrated solar radiation during the seedling stage was approximately $8 \mathrm{MJ} \cdot \mathrm{m}^{-2}$ until the Jun. crop. The solar radiation was highest during the Jul. crop and lowest during the Aug. crop.

Total fruit counts and yields (Fig. 3), which included unmarketable fruits, in the control from Feb. crop to May crop were significantly higher than in those from Jun. crop to Aug. crop. The total fruit count in the control was the highest in Apr. crop. In any crops, total fruit count was lower in heavy shading than in the control but unaffected by light or medium shading. Total fruit 


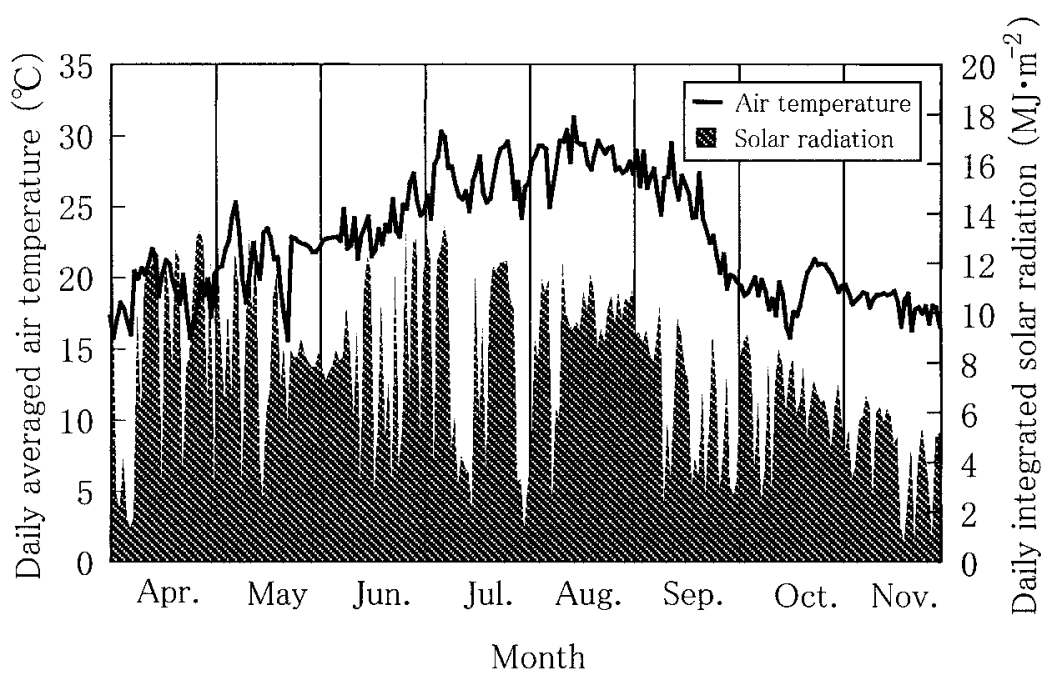

Fig. 2. Daily averaged air temperature and daily integrated solar radiation in control.

Table 1. Abstracts of crops.

\begin{tabular}{|c|c|c|c|c|c|c|}
\hline \multirow[b]{2}{*}{ Month of seeding } & \multirow[b]{2}{*}{ Date of anthesis } & \multirow[b]{2}{*}{ Date of harvest } & \multicolumn{2}{|c|}{ Air temperature $\left({ }^{\circ} \mathrm{C}\right)$} & \multicolumn{2}{|c|}{ Solar radiation $\left(\mathrm{MJ} \cdot \mathrm{m}^{-2}\right)$} \\
\hline & & & Seedling stage ${ }^{\mathrm{z}}$ & $\begin{array}{l}\text { Fruit developing } \\
\text { stage }^{y}\end{array}$ & Seedling stage & $\begin{array}{c}\text { Fruit developing } \\
\text { stage }\end{array}$ \\
\hline February & $16 \mathrm{Apr}$ & 30 May & $-^{x}$ & 20.7 & - & 8.8 \\
\hline March & $30 \mathrm{Apr}$ & 15 Jun & 18.9 & 21.9 & 8.2 & 8.4 \\
\hline April & 29 May & $8 \mathrm{Jul}$ & 21.4 & 24.5 & 8.5 & 8.6 \\
\hline May & 21 Jun & $27 \mathrm{Jul}$ & 22.9 & 26.6 & 7.9 & 8.5 \\
\hline June & $23 \mathrm{Jul}$ & 27 Aug & 27.0 & 28.4 & 8.5 & 8.8 \\
\hline July & 20 Aug & $25 \mathrm{Sep}$ & 28.7 & 25.0 & 9.3 & 7.3 \\
\hline August & 19 Sep & $11 \mathrm{Nov}$ & 26.2 & 19.0 & 6.6 & 5.8 \\
\hline
\end{tabular}

Each value is a mean in control.

${ }^{\mathrm{z}}$ Means a period between the transplanting into rockwool cube and the first flower anthesis.

${ }^{y}$ Means a period between the first flower anthesis and the first fruit harvest.

${ }^{x}$ No data because of the fragmentation of recorded data.

yield in the control was the highest in Feb. crop; but it was relatively high in Mar., Apr. and May crops, and low in Jun., Jul. and Aug. crops. In any crop, the total fruit yield was affected significantly by shading; it decreased as the shading level increased.

The results of regression analysis between total fruit yield and the average daily integrated solar radiation during fruit development (Table 2) reveal that the regression coefficient was small in Jun. and Jul. crops. In these two crops, $R^{2}$ values were also lower than those in other crops. Relationships between the regression coefficient and constant of the regression equations and the averaged air temperature in fruit developing stage in each crop (Fig. 4) shows that as the air temperature increased, the regression coefficient of each crop excluding Jun. and Jul. crops also increased linearly $\left(R^{2}=0.879\right)$; the constant of each crop excluding Jun. crop decreased linearly $\left(R^{2}=0.895\right)$.

Percentages, fresh weights per fruit, and yields per plant of marketable fruits (Fig. 5) show that marketable fruit in control declined from Apr. crop to Jun. crop, becoming the lowest in Jun. crop, and then increased in Aug. crop. Under heavy shading, the percentage of marketable fruit decreased in most crops. However, under medium or light shading, the percentages of marketable fruits ranged from 50 to $98 \%$ in all crop treatments; during May to Jul. crop treatments, the percentages were higher than those of the control.

Marketable fruit weight of control was the highest in Feb. crop and the lowest in Jul. crop; it was not significantly different from Mar. crop to Aug. crop except for that in Jul. crop. The marketable fruit weights were significantly affected by shading. Increased shading level decreased the fruit weight in all crops. However, the marketable fruit weight was not decreased by light shading in Apr., May, Jul. and Aug. crops.

Yield of marketable fruit in the control fluctuated seasonally, similar to the percentage. The marketable fruit yield declined during Feb. crop to Jun. crop, and dropped to the lowest point in Jun. crop, and then increased up to the level of Mar. crop in Aug. crop. Except for May, Jun. and Jul. crops, the marketable fruit 


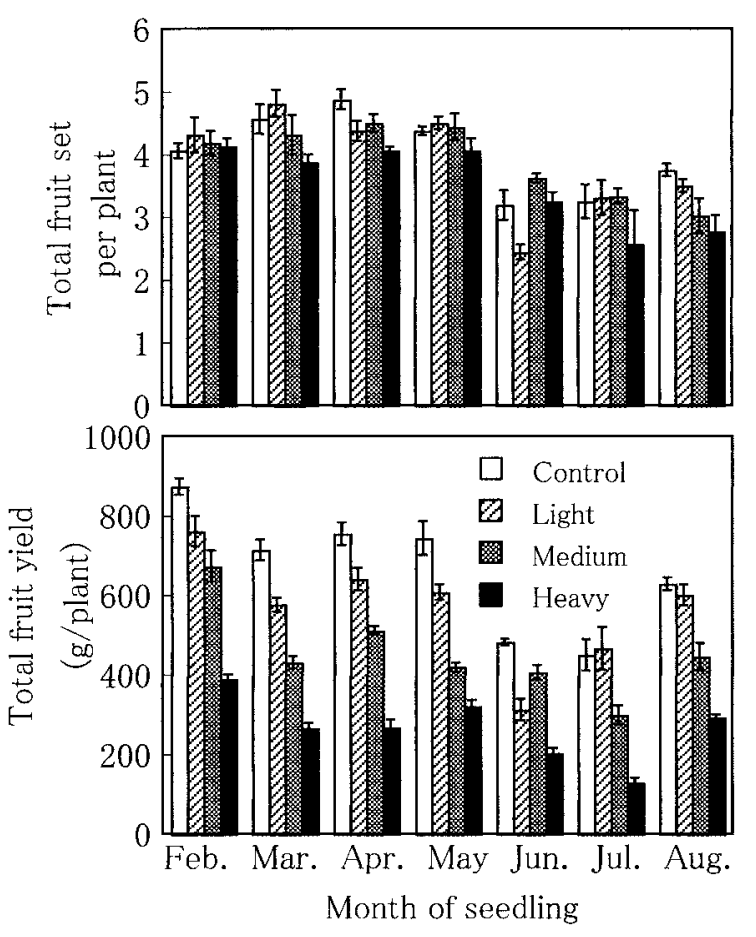

Fig. 3. Effects of shading on the total fruit set and total fruit yield of tomatoes grown on a single-truss system. Vertical bars indicate $\operatorname{SE}(n=4)$.

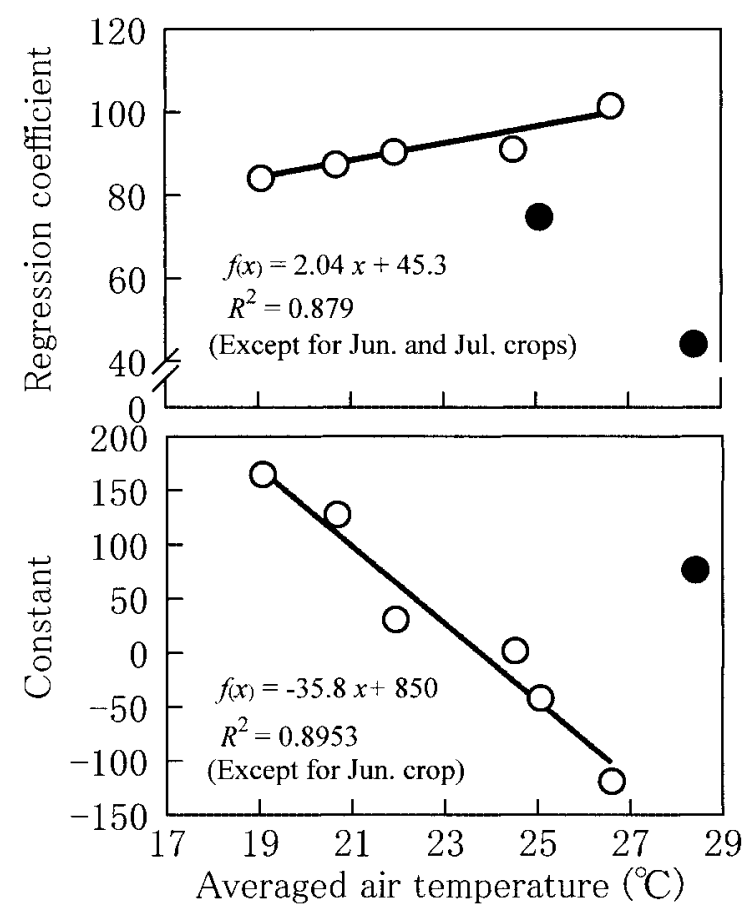

Fig. 4. Relationship between the regression coefficient and constant in each crop and the averaged air temperature from the first flower anthesis to the first fruit harvest. Closed symbols represent the points excluded from regression lines.

Table 2. Regression analysis of total fruit yield on the averaged daily integrated solar radiation from the first flower anthesis to the first fruit harvest.

\begin{tabular}{cccc}
\hline \hline Month of seeding & Regression coefficient & constant & $R^{2}$ \\
\hline February & 87.7 & 129 & 0.87 \\
March & 90.7 & 32 & 0.96 \\
April & 91.4 & 3 & 0.92 \\
May & 101.8 & -118 & 0.93 \\
June & 44.5 & 78 & 0.62 \\
July & 75.1 & -41 & 0.72 \\
August & 84.4 & 166 & 0.83 \\
\hline
\end{tabular}

yields decreased corresponding to the shading level. However, the marketable fruit yields increased by some levels of shading during the summer. Compared with the control, light shading in May crop, every shading treatments in Jun. crop and light and medium shading in Jul. crop increased the marketable fruit yield.

Percentages of small fruit and cracked fruit (Fig. 6) indicate that the percentage of small fruit was increased by heavy shading in any crop; it exceeded $30 \%$ from Mar. crop to reach $57 \%$ in the Jul. crop, whereas it was less than $10 \%$ in the control, light and medium shading in most crops. The percentage of cracked fruit in the control increased in summer-harvested fruit; the percentage was more than $38 \%$ from May to Jul. crop and reached $78 \%$ in Jun. crop. Any levels of shading decreased the percentage of cracked fruits and the percentage decreased inversely to the shading level.

Fruit brix under control gradually decreased from Apr. crop to Jul. crop (Fig. 7); it tended to decrease as shading level increased. Titratable acidity of the fruits was very high in some levels of shading in Jun. and Jul. crops compared with Apr. and May crops. The titratable acidities in medium and heavy shading were higher than those in control and light shading in Jul. crop. However, effects of shading on the acidity were not clear in other crops.

\section{Discussion}

In this study we tried to determine the yield and quality of tomato fruit under shading, which is usually carried out to relieve the plants from high air temperature and strong solar radiation in the summer. Two major problems were encountered during our experiments: one, the difficulty to grow tomato plants in mid-summer, and two, a remarkably low number of fruit set under shading, especially in summer. 

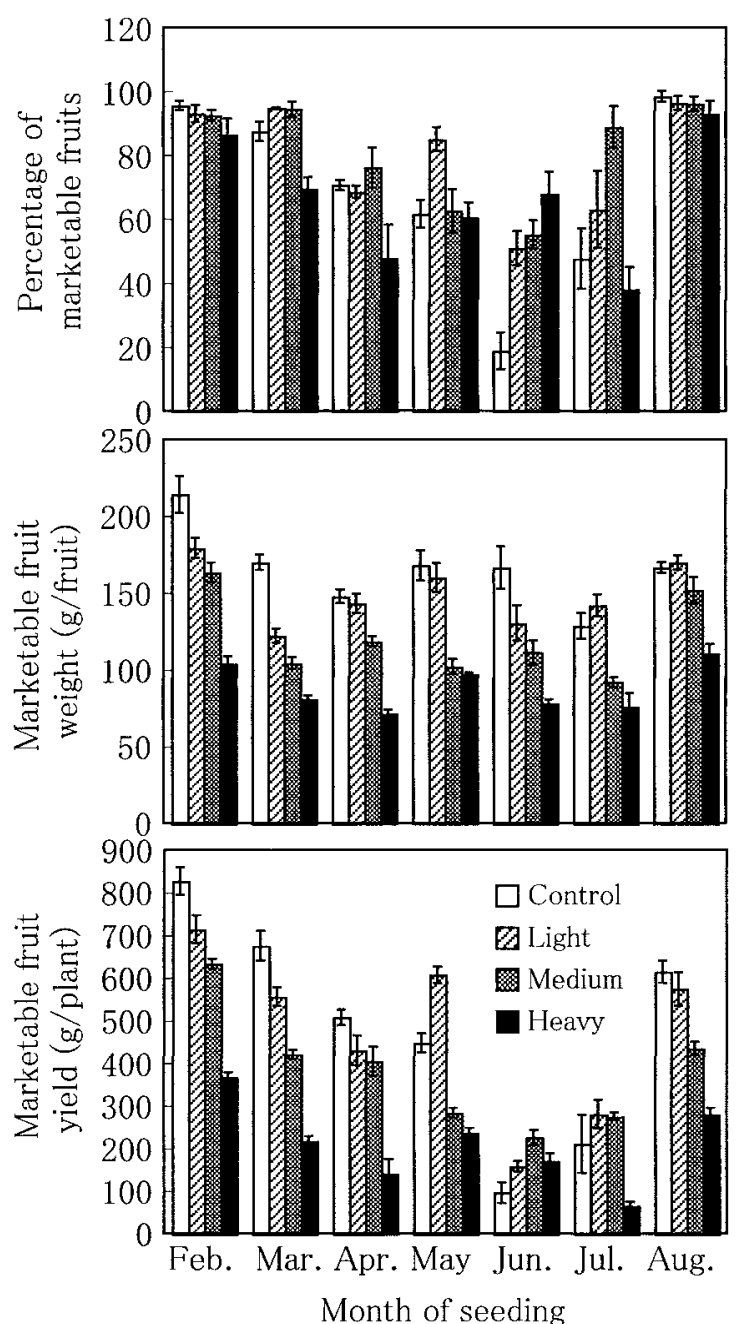

Fig. 5. Effects of shading on the percentage, weight and yield of marketable fruit in tomatoes grown on a single-truss system. Vertical bars indicate SE $(n=4)$.

It has been known that root-zone cooling enables fruit vegetables to grow during the hot summer (Sasaki and Itagi, 1989). Sasaki (1991) reported that it became possible to grow tomato plants during hot summer when the nutrient solution was cooled to $25^{\circ} \mathrm{C}$. Accordingly, the nutrient solution supplied to the plants was cooled to $25^{\circ} \mathrm{C}$ from July to September in our experiments.

Sato et al. (1994) reported that fruit set was very small and no fruit was harvested when tomato plants were shaded by $80 \%$ at flowering period. Low light condition at flowering induced complete abortion of truss (Kinet, 1977). To insure fruit set, shading was started 10 days after the first anthesis in our experiments. Consequently, the delay in shading did not cause a difference in fruit set between the control and shaded plants in most crops (Fig. 4).

\section{Seasonal change of the fruit yield in control}

Total fruit yield in our experiment was low in the summer. The decrease in the total fruit yield in summer

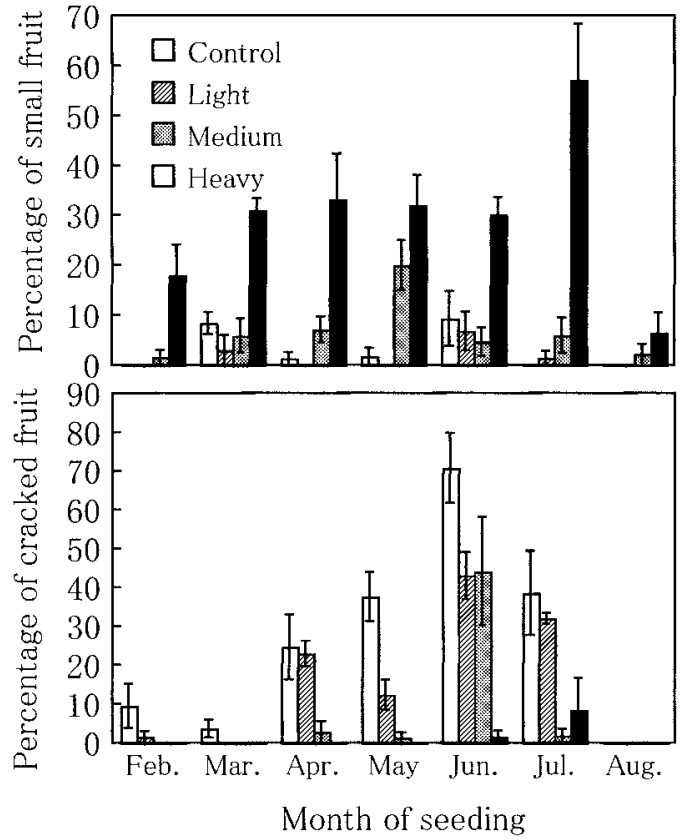

Fig. 6. Effects of shading on the percentage of small fruit, weighing less than $50 \mathrm{~g}$, and cracked tomatoes grown on a single-truss system. Vertical bars indicate SE $(n=4)$.
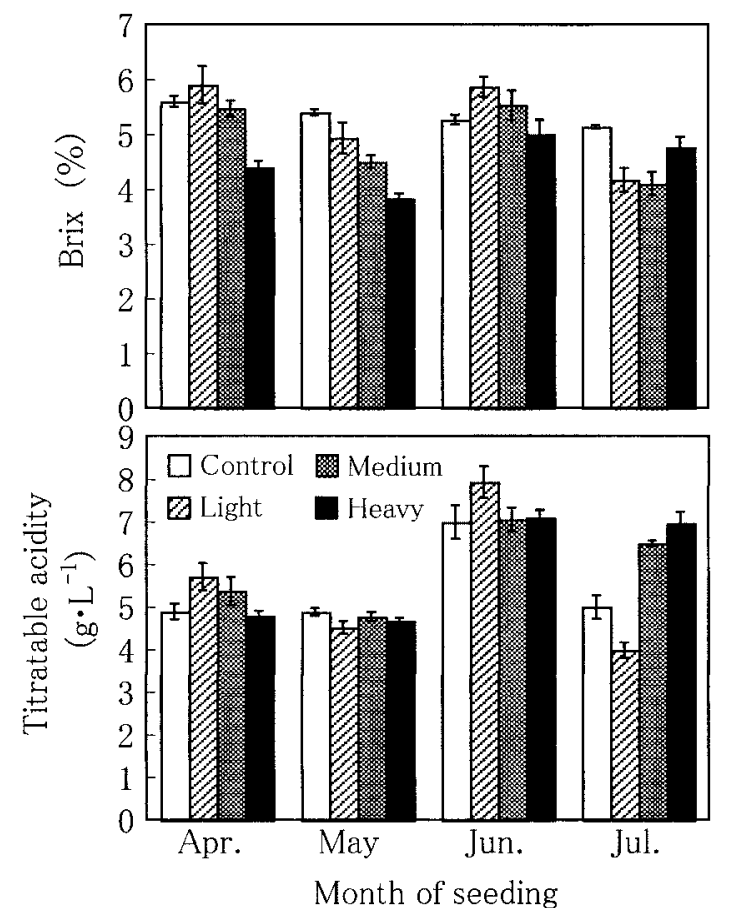

Fig. 7. Effects of shading on the brix and titratable acidity of fruit in tomatoes grown on a single-truss system. Vertical bars indicate SE $(n=5)$.

was mainly caused by low fruit sets. It was reported that the fruit number in tomato plants increased under low air temperature during the seedling stage in winter (Hurd and Cooper, 1967). However the effect of high air temperature on the fruit number is not clearly understood. The average air temperatures during the seedling stage 
in Jun., Jul., and Aug. crops in our experiment were $27.0,28.7$, and $26.2^{\circ} \mathrm{C}$, respectively. Although more experiments are needed to test the effect of high air temperature on fruit set of tomato plants, our data show that an excess over $26^{\circ} \mathrm{C}$ during the seedling stage may decrease fruit set per truss.

That the marketable fruit yield was the highest in the Feb. crop and decreased in the summer indicates that it was mainly caused by low fruit set in summer. Over $50 \%$ of the unmarketable fruits were cracked as was reported by Yamashita et al. (1992) who studied the year-round tomato-production system. In our experiment, more than $38 \%$ of fruits cracked in May, Jun., and Jul. crops, during which air temperatures were 26.6, 28.4 , and $25.0^{\circ} \mathrm{C}$, respectively. The results suggest that high air temperature may cause a high incidence of cracked fruits.

Fruit weight was the highest in the Feb. crop and fluctuated seasonally in the control. It was evident that fruit weight was affected by air temperature before and after anthesis; low air temperatures in both periods increased fruit weight (Wada et al., 1998, 2001). Thus, higher fruit weight in the Feb. crop could be attributed to the lower air temperature as compared with other crops, but the effect of high air temperature on the fruit weight is not clear. Final fruit weight is governed by both fruit growth rate and days of fruit development (Hurd and Graves, 1985; Nagaoka et al., 1979). To explain how high air temperature affects tomato fruit weight, further investigation on the effects of air temperature on the fruit growth rate and the period of fruit development in summer is needed.

\section{Effects of shading on the fruit yield}

Shading clearly affected fruit yield by decreasing fruit weight and confirms the findings of Cockshull et al. (1992) and Sato et al. (1994). Positive correlation between the fruit yield in single-truss tomatoes and the mean value of daily integrated solar radiation after transplanting (Hisatomi and Fujimoto, 1978) and the cumulative solar radiation (Giniger et al., 1988) were also reported. It is useful to have information regarding yield loss by shading. Our regression analysis between the total fruit yield and the averaged value of daily integrated solar radiation during fruit developing stage (Table 2) also show that the regression coefficients became larger as air temperature in fruit developing stage increased (Table 2, Fig. 4). The result means that the degree of yield loss by shading increased as the air temperature rose. From these data we developed the following equation.

$$
y=2.04 x+45.3
$$

in which, $y$ : regression coefficient of total fruit yield (g/plant) on averaged value of daily integrated solar radiation $\left(\mathrm{MJ} \cdot \mathrm{m}^{-2}\right)$ received by the plants at fruit developing stage; $x$ : averaged air temperature $\left({ }^{\circ} \mathrm{C}\right)$ at the same period. The $y$ value is the total fruit yield per plant in grams that would decrease when the daily integrated solar radiation decreased by $1 \mathrm{MJ} \cdot \mathrm{m}^{-2}$. The equation (1) shows that the decrease of total fruit yield by loss of $1 \mathrm{MJ} \cdot \mathrm{m}^{-2}$ of daily integrated solar radiation would become 84 to 100 (g/plant) when the air temperature changed from 19 to $27^{\circ} \mathrm{C}$. This result shows that the decrease of total fruit yield by loss of solar radiation would become larger as the air temperature increased.

The constant of the regression lines (Table 2) is also affected by air temperature; it becomes smaller when the air temperature is high, indicating that the fruit yield in the plant that received the same averaged daily integrated solar radiation would decrease as the air temperature rose. It also might be possible to predict total fruit yield by using two equations shown in Fig. 4. However, these equations could not be adapted to Jun. and Jul. crops. The averaged air temperatures during seedling and fruit developing stages were 27.0 and $28.4^{\circ} \mathrm{C}$ in the Jun. crop and 28.7 and $25.0^{\circ} \mathrm{C}$ in the Jul. crop, respectively. Such high temperatures might inhibit normal development of tomato plants. Therefore the equations in Fig. 4 could be applied when the averaged air temperatures during both of seedling and fruit developing stages range between 19 and $27^{\circ} \mathrm{C}$. This findings might be associated with the changes in photosynthetic rate, loss of photosynthetic assimilate by respiration, partitioning of carbohydrates or period for fruit development, etc., under higher air temperature because the regression coefficient and the constant of regression line in Table 2 indicate that thsese factors are affected by air temperature.

The shading decreased the incidence of cracked fruit indicates that some unmeasured environmental factors affected tomato growth. High relative humidity and high concentration of nutrient solution increased cracked fruit, whereas light irradiance in the night decreased the incidence of cracked fruit of hydroponically grown cherry type tomatoes (Ohta et al., 1991, 1993, 1998). Low vapor pressure deficit (Leonardi et al., 2000), twisting peduncle (Yamashita and Hayashi, 1994) decreased the incidence of cracked tomatoes. However, the relationship between shading and the incidence of cracked fruit was not been clarified. The results in our experiment show that shading significantly reduced the incidence of cracked fruit and that some levels of shading in hot summer season could increase marketable fruit yield in spite of the decrease of fruit weight. It was reported that incidence of cracked fruit in single-truss tomatoes decreased with decreasing fruit weight by osmotic stress in root-zone after anthesis (Ikeda et al., 1999). Decrease of fruit weight by shading could decrease the incidence of cracked fruit. Another possible cause of the decrease of cracked fruit by shading is a decreased fruit temperature by the shading treatments. Cockshull et al. (1992) showed that shading also decreased fruit temperature by 3 to $5^{\circ} \mathrm{C}$. 
The highest marketable fruit yield in May, Jun., and Jul. crops resulted from light, medium and light shading, respectively. In these combinations of crop and shading treatment, the averaged air temperature and the averaged values of daily integrated solar radiation during fruit developing stage were $26.6,28.4$, and $25.0^{\circ} \mathrm{C}$, and 6.0 , 4.0 , and $5.1 \mathrm{MJ} \cdot \mathrm{m}^{-2}$, respectively. Therefore, it is thought that decreasing the solar radiation to $5-6 \mathrm{MJ} \cdot \mathrm{m}^{-2}$ by shading might effectively increase marketable fruit yield when the average air temperature rises above $25^{\circ} \mathrm{C}$. Similarly, decreasing the solar radiation to about $4 \mathrm{MJ} \cdot \mathrm{m}^{-2}$ might be recommended when the air temperature exceeds $28^{\circ} \mathrm{C}$.

\section{Fruit quality}

It was well known that shading decreased sugar content of tomato fruit (McCollum, 1946; Yanagi et al., 1995). Similar results were observed in brix of our experiment. The quality of fruits harvested during the hot summer was characterized by high titratable acidity. However, the effect of shading on the acidity was not clear in our experiment. Sakiyama (1968) reported that titratable acidity was increased by high air temperature but unaffected by shading, just as we found. However, shading increased titratable acidity in another paper (Yanagi et al., 1995), which agrees with the result of our Jul. crop. It was also reported that acidity was changed by fruit set order, the acidity of apical fruit in a truss was higher but it was less sensitive to shading than that of basal fruit in the same truss (Yanagi et al., 1995). Fruit-set order was not considered in our experiment, and that may explain why the effect of shading on acidity was indifferent.

\section{Literature cited}

Cockshull, K. E., C. J. Graves and C. R. J. Cave. 1992. The influence of shading on yield of glass house tomatoes. J. Hort. Sci. 67: 11-24.

Davis, J. N. and G. E. Hobson. 1981. The constituents of tomato fruit-The influence of environment, nutrition, and genotype. CRC Critical Reviews in Food Sci. and Nutri. 15: 205-280.

Giniger, M. S., R. J. McAvoy, G. A. Giacomelli and H. W. Janes. 1988. Computer simulation of a single truss tomato cropping system. Amer. Soc. Agr. Engineers 31: 11761179.

Hisatomi, T. and K. Fujimoto. 1978. Studies on the single truss tomato culture. I. Growth and yield for sowing at different dates over the year. J. Japan. Soc. Hort. Sci. 46: 487-494 (In Japanese with English summary).

Hurd, R. G. and A. J. Coopper. 1967. Increasing flower number in single-truss tomatoes. J. Hort. Sci. 42: 181-188.

Hurd, R. G. and C. I. Graves. 1985. Some effects of air and root temperatures on the yield and quality of glasshouse tomatoes. J. Hort. Sci. 45: 19-27.

Ikeda, T., Y. Sakamoto, S. Watanabe and K. Okano. 1999. Water relations in fruit cracking of single-truss tomato plants. Environ. Control in Biol. 37: 153-158.

Iwahori, S., R. Sakiyama and K. Takahashi. 1963. High temperature injuries in tomatoes. I. Effects of different temperatures on fruit setting and yield of seedlings treated at different stages of growth. J. Japan. Soc. Hort. Sci. 32: 197-204 (In Japanese with English summary).

Kinet, J. M. 1977. Effect of light conditions on the development of the inflorescence in tomato. Scientia Hortic. 6: 15-26.

Kobayashi, S., H. Shimaji and H. Ikeda. 1998. A study on single-truss tomato production by hydroponics. II. Relationship between environmental parameters and plant growth. J. Soc. Agr. Structures, Japan. 28: 203-208 (In Japanese with English summary).

Leonardi, C., S. Guichard and N. Bertin. 2000. High vapor pressure deficit influences growth, transpiration and quality of tomato fruits. Scientia Hortic. 84: 285-296.

Lipton, W. J. 1970. Effects of high humidity and solar radiation on temperature and color of tomato fruits. J. Amer. Soc. Hort. Sci. 95: 680-684.

McAvoy, R. J., H. W. Janes, G. A. Giacomelli and M. S. Giniger. 1989. Validation of a computer model for a single-truss tomato cropping system. J. Amer. Soc. Hort. Sci. 114: 746-750.

McCollum, J. P. 1946. Some factors affecting the ascorbic acid content of tomatoes. Proc. Amer. Soc. Hort. Sci. 45: 382386.

Mulholland, B. I., R. N. Edmondson, M. Fussell, J. Basham and L. C. Ho. 2003. Effects of high temperature on tomato summer fruit quality. J. Hort. Sci. Biotech. 78: 365-374.

Nagaoka, M., K. Takahashi, K. Arai, T. Hanada and H. Yoshioka. 1979. Effects of light intensity, night temperature and $\mathrm{CO}_{2}$ concentration on the growth and yield of glasshouse tomato. Bull. Natl. Res. Inst. Veg. A6: 105-122 (In Japanese with English summary).

Nasiruddin, K. M., A. F. M. Sharfuddin and R. Begun. 1995. Effect of different shading treatments on growth, yield and quality of tomato cv Roma VF and Marglobe. Punjab Vegetable Grower 30: 35-44.

Ohta, K., N. Ito, T. Hosoki, K. Endo and O. Kajikawa. 1993. Influence of the nutrient solution concentrations on cracking of cherry tomato fruit grown hydroponically. J. Japan. Soc. Hort. Sci. 62: 407-412.

Ohta, K., N. Ito, T. Hosoki and Y. Sugi. 1991. Influence of relative-humidity on fruit cracking of cherry tomato grown on hydroponic culture and its control. J. Japan. Soc. Hort. Sci. 60: 337-343 (In Japanese with English summary).

Ohta, K., K. Tsurunaga and T. Hosoki. 1998. Possibility of controlling fruit-cracking in cherry tomatoes by light treatment at night. J. Japan. Soc. Hort. Sci. 67: 216-218.

Saito, T. 2004. Seiikusuteji to seiri, seitai. p. 19-169. In: Noubunkyo (eds.). Tomato. Yasaiengeidaihyakka. 2nd ed. vol. 2. Nousangyosonbunkakyoukai. Tokyo (In Japanese).

Sakamoto, Y., S. Watanabe, T. Nakashima and K. Okano. 1999. Effects of salinity at two ripening stages on the fruit quality of single-truss tomato grown in hydroponics. J. Hort. Sci. Biotech. 74: 690-693.

Sakiyama, R. 1968. Effects of irrigation, temperature and 
shading on the acidity of tomato fruits. J. Japan. Soc. Hort. Sci. 37: 67-72 (In Japanese with English summary).

Sasaki, K. 1991. Establishment of a year-round tomato production by topping at the second truss stage using NFT. Environ. Control in Biol. 29: 117-126 (In Japanese with English summary).

Sasaki, K. and T. Itagi. 1989. Effect of root cooling treatment of nutrient solution on growth and yield of tomato, cucumber and melon. Environ. Control in Biol. 27: 8995 (In Japanese with English summary).

Sato, H., T. Yanagi, H. Hirai, E. Ueda and Y. Oda. 1994. Effects of shading on growth, fruit yield and dry matter partitioning of single truss tomato plants. Environ. Control in Biol. 32: 231-237 (In Japanese with English summary).

Slack, G., J. S. Fenlon and D. W. Hand. 1988. The effects of summer $\mathrm{CO}_{2}$ enrichment and ventilation temperature on the yield, quality and value of glasshouse tomatoes. J. Hort. Sci. 63: 119-129.

Wada, T., H. Ikeda, K. Morimoto and H. Furukawa. 1998. Effects of minimum air temperature on the growth, yield and quality of tomatoes grown on a single-truss system. J. Japan. Soc. Hort. Sci. 67: 420-425 (In Japanese with
English summary).

Wada, T., H. Ikeda, K. Morimoto, H. Furukawa and K. Abe. 2001. Effects of minimum air temperature during raising seedlings on the plant growth, yield, and fruit quality of tomatoes grown on a single-truss system. J. Japan. Soc. Hort. Sci. 70: 733-739 (In Japanese with English summary).

Yamashita, F., M. Aoyagi and G. Hayashi. 1992. Studied on the year-round production system of tomato in rockwool culture. I. Effects of sowing date, pinching node-order and planting density. Res. Bull. Aichi Agr. Res. Center. 24: 115-122 (In Japanese with English summary).

Yamashita, F. and G. Hayashi. 1994. Studies on the year-round production system of tomato in water culture. II. Method for prevention of fruit cracking in high temperature period. Res. Bull. Aichi Agr. Res. Center. 26: 157-162 (In Japanese with English summary).

Yanagi, T., E. Ueda, H. Sato, H. Hirai and Y. Oda. 1995. Effects of shading and fruit set order on fruit quality in single truss tomato. J. Japan. Soc. Hort. Sci. 64: 291-297 (In Japanese with English summary).

\author{
夏季の遮光が一段栽培したトマト果実の収量と品質に及ぼす影響 \\ 和田光生・池田英男 - 松下健司 - 神原 晃 - 平井宏昭 - 阿部一博 \\ 大阪府立大学大学院農学生命科学研究科 599-8531 堺市学園町
}

\footnotetext{
トマトを 2 月から 8 月まで毎月 10 日に播種し, NFT ベッドで一段栽培した。一番花開花 10 日後より遮光率 $0 \%$ (対照区)，30\%（弱遮光），55\%（中遮光）および $83 \%$ (強遮光)の寒冷紗で被覆することによって遮光処理を開 始し，果実の収量と品質を調査した。7月から9月まで は給液する培養液を $25{ }^{\circ} \mathrm{C}$ に冷却した。遮光率が増加す るにつれて，1 果重が減少して全果実収量は低下した. 全果実収量は播種月ごとに果実発達期の平均日積算日射 量によって直線で回帰された．回帰分析の結果から，果 実発達期の平均気温が $19{ }^{\circ} \mathrm{C}$ から $27{ }^{\circ} \mathrm{C}$ 高まった場合,
}

平均日積算日射量 $1 \mathrm{MJ} \cdot \mathrm{m}^{-2}$ の減少に伴ら収量低下量は, 84 から $100 \mathrm{~g} /$ 株に増加することが示された. 対照区の可 販果収量は 2 月播種で最も高く, 4 月から 7 月播種では 裂果の発生によって有意に低下した。裂果の発生は遮光 によって有意に抑制された。平均気温が $25{ }^{\circ} \mathrm{Cを}$ 超えた 場合には，日平均積算日射量を $5 \sim 6 \mathrm{MJ} \cdot \mathrm{m}^{-2}$ 程度まで 低下させる遮光によって，可販果収量は増加する効果が 認められた。夏季高温時に収穫される果実は滴定酸含量 が高かった，遮光によって，果実の糖度は低下し，滴定 酸含量は増加する傾向が認められた. 